\title{
Possible protective effect of quercetin against oxidative stress in liver from metabolic syndrome rats
}

\section{Metabolik sendromlu sıçanların karaciğerlerinde oksidatif strese karşı kuersetinin olası koruyucu etkisi}

\author{
(1) Ayça Bilginoğlu \\ Department of Biophysics, Ankara Yıldırım Beyazıt University Faculty of Medicine, Ankara, Turkey
}

\begin{abstract}
Introduction: Metabolic syndrome (MS) is linked to a type of type 2 diabetes mellitus associated with high glucose level and insulin resistance. Thioredoxin-1 (TRX-1) is localized in the cytoplasm and the mitochondria and controls cellular reactive oxygen species. The purpose of this study is to examine the relation between MS and oxidative stress, and effect of quercetin on oxidative stress via TRX1 in liver of MS rats.
\end{abstract}

Methods: Male Wistar rats (200-250g in weight) were used. They were divided three groups. Control group, MS group receiving (935 $\mathrm{mM}$ sucrose in drinking water) and quercetin treated $(15 \mathrm{mg} / \mathrm{kg} /$ day, administered by gavage) MS group. Protein level of TRX-1 was determined by Western blot.

Results: Aspartate transaminase (AST), alanine transaminase (ALT), lactate dehydrogenase (LDH), levels increased in MS group as compared with the Con group. Total-antioxidant-status (TAS), superoxide-dismutase (SOD), and glutathione-peroxidase (GSH-Px) levels decreased in MS group when compared to Con group. Total-oxidant-status (TOS) levels increased in MS group as compared with the Con group. Triglycerides, total-cholesterol and LDL-cholesterol increased in MS group when compared with the Con group. TRX-1 level decreased in MS group and TRX-1 activity was lower in MS group than Con group.

Discussion and Conclusion: Treatment of quercetin decreased AST, ALT, LDH, and TOS levels while it increased GSH-Px, SOD, and TAS levels. Also, lipid profile changed with quercetin. In conclusion, treatment of quercetin significantly increased TRX-1 level and activity of TRX-1 in MS group. These data suggest that elevated oxidative stress in liver of MS may be reduced by quercetin.

Keywords: Insulin resistance; liver; metabolic syndrome; oxidative stress; quercetin.

\section{Özet}

Amaç: Metabolik sendrom (MS), yüksek şeker düzeyi ve insülin direnci ile ilişkilendirilen tip 2 diyabetin tipine bağlıdır. Tiyoredoksin-1 (TRX-1) sitoplazma ve mitokondride yerleşmiştir ve hücresel reaktif oksijen türlerini kontrol eder. Bu çalıșmanın amacı, MS sıçanların karaciğerinde, MS ve oksidatif stres arasındaki ilişkiyi ve kuersetinin TRX-1 bağlantıl oksidatif stres üzerindeki etkisini araştırmaktır.

Gereç ve Yöntem: Erkek Wistar sıçanlar (200-250g ağırlığında) kullanıldı. Üç gruba ayrıldılar. Kontrol grup, MS grup (935 mM sükroz içeren içme suyu) ve kuersetin uygulanmış (15 mg/kg/gün, gavaj ile) MS grup. TRX-1 protein seviyesi Western blot ile belirlenmiştir.

Bulgular: MS gruptaki aspartat transaminaz (AST), alanin transaminaz (ALT), laktat dehidrojenaz (LDH) seviyeleri Kon grubu ile karşılaştıııldığında arttı. MS grubundaki toplam-antioksidan-durumu (TAS), süperoksit-dizmutaz (SOD), ve glutatyon-peroksidaz (GSH-Px) seviyeleri Kon grubu ile karşılaştıııldığında azaldı. MS grubundaki toplam-oksidan-durumu (TOS) seviyesi Kon grubu ile karşılaştıııldığında azaldı. MS grubundaki trigliserit, toplam-kolesterol ve LDL-kolesterol Kon grubu ile karşılaştıııldığında arttı. MS grubundaki TRX-1 seviyesi Kon grubu ile karşılaştıııldığında azalırken TRX-1 aktivitesi ise düştü.

Sonuç: Kuersetin tedavisi AST, ALT, LDH, ve TOS seviyelerini azaltırken GSH-Px, SOD, ve TAS seviyelerini artırdı. Ayrıca, yağ profili de kuersetin ile değişti. Sonuç olarak, Kuersetin tedavisi, MS grubundaki TRX-1 seviyesini ve aktivitesini önemli derecede artırdı. Bu veriler MS karaciğerinde artmış olan oksidatif stresin kuersetin ile azalabildiğini ileri sürmektedir.

Anahtar Sözcükler: Insülin direnci; karaciğer; metabolik sendrom; kuersetin; oksidatif stres.

Corresponding (illetişim): Ayça Bilginoğlu, Ankara Yıldırım Beyazıt Üniversitesi Tıp Fakültesi, Biyofizik Anabilim Dalı, Ankara, Turkey 
$\mathrm{M}$ etabolic syndrome (MS) is a medical disorder that it is inked to insulin resistance, overweight, adiposity, hypertriglyceridemia. ${ }^{[1]}$ MS is also associated with oxidative stress which reflects an imbalance between the production and inactivation of reactive oxygen species. ${ }^{[2]}$

Oxidative stress is resulted by when reactive forms of oxygen would produce faster than they could be neutralized by antioxidants. ${ }^{[3]}$ Also, oxidative stress can produce an alteration of protein and nucleic acid structure, damage to membrane ion transport and permeability, destruction of the cells by lipid peroxidation. ${ }^{[4]}$ In chronic hyperglycemia, there is a depletion of the activity of the antioxidative defense system. Thus it promotes free radical generation. ${ }^{[5,6]}$

Non-alcoholic fatty liver disease (NAFLD) may progress to cirrhosis and its complications. The pathogenesis of cellular injury and steatosis is thought to be related mostly to insulin resistance and oxidative stress. Moreover, lots of studies reported that nonalcoholic fatty liver disease precedes and is a risk factor for the future development of the MS. ${ }^{[7,8]}$

Quercetin, a natural flavonoid, is a compound with antioxidant and anti-inflammatory activity. ${ }^{[9]}$ Quercetin, like other flavonoids, acts as a quencher for reactive oxygen species generated by any physical or chemical action. ${ }^{[10]}$ Xanthine oxidase and lipid peroxidation are inhibited by quercetin. ${ }^{[1]}$

Thioredoxin (TRX) system maintains proteins in a reduced state under physiological conditions and modulates the physiological function of proteins which are susceptible to oxidation. ${ }^{[12]}$ TRX is characterized by the presence of three conserved prolines. This proline is the key residue that determines the reducing power of TRX and replacing it by a serine or a threonine has a dramatic effect on the redox and stability properties of the protein. ${ }^{[13]}$ Cellular protection against oxidative damage of proteins involves the activity of TRX-1 system. ${ }^{[14]}$

The aim of this present study was to evaluate the beneficial and preventive effects of quercetin on oxidative stress and TRX-1 in liver tissues of MS rats.

\section{Materials and Method}

\section{Animals and induction of metabolic syndrome}

Three-months-old male Wistar Albino rats (200-250g) were used and maintained under standardized conditions (12-hour (h) light/ dark cycle, $24 \pm 2^{\circ} \mathrm{C}, 35-60 \%$ humidity). Female hormones may protect the animals from the oxidative stress of MS. So in the present study, we used male rats. ${ }^{[15]}$ Rats were fed with standard laboratory chow (dietary composition of rat diet contained (as percentage): torula yeast 30.0, corn oil 2.0, sucrose 59.0, DL-methionine 0.3 and AIN-76 TM mineral mixture 5.0 and AIN-76 TM vitamin mixture 1.0 with digestible energy $12.59 \mathrm{MJ} / \mathrm{kg}$ from Horland Tekland, Madison, WI, USA) with free access to water. At the end of the experimental period, animals were anesthetized after being deprived of food for $12 \mathrm{~h}$. The animals were randomly divided into the three groups consisting of 8 rats each. Control group (Con) received standard laboratory diet and drinking water. Metabolic syndrome induced group (MS) received 32\% sucrose (935 mM) including drinking water for 20 weeks. $^{[16]}$ Quercetin treated MS group (MS-Q) received quercetin treatment $(15 \mathrm{mg} / \mathrm{kg} /$ day, via oral gavage, Sigma) for two weeks at the end of the $18^{\text {th }}$ weeks of MS group. Quercetin was dissolved in corn oil. Homeostatic model assessment (HOMA) is a method for assessing $\beta$-cell function and insulin resistance (IR) from basal (fasting) glucose and insulin concentrations. HOMA-IR is calculated using following formula: HOMA-IR=fasting blood glucose $(\mathrm{mmol} / \mathrm{L}) \times$ fasting insulin $(\mathrm{mU} / \mathrm{L}) / 22.5$. HOMA- $\beta$ is calculated using following formula: HOMA- $\beta=[20 \times$ fasting insulin $(\mathrm{mU} / \mathrm{L})] /[$ fasting glucose $(\mathrm{mmol} / \mathrm{L})-3.5] .^{[17,18]}$ The units used according to IU (International units of system). Insulin was measured using commercial kits (Cayman). All animal procedures and experiments described in present study were approved by the Animal Ethics Committee of Ankara University Faculty of Medicine (2015-2-37).

\section{Tissue homogenization}

Livers were homogenized with a motor-driven teflon to glass homogenizer in cold (mM) TrisHCl 20 (pH 7.4), $\mathrm{NaCl} 150, \mathrm{KCl} 2$, EDTA 2, DTT 0.5, protease inhibitor cocktail 100, PMSF 0.4 and $2 \% \mathrm{NP}-40$. And then centrifugation step was done to separate the cell membrane and cytosol. Protein content of cytosol was used in biochemical assays and western blot measurement.

\section{Biochemical assays}

After homogenization of liver tissues, protein content was analyzed using the Bradford method (Bio-Rad), and bovine serum albumin was used as the standard. Then, important enzymes such as aspartate aminotransferase (AST) (Biovision), alanine transaminase (ALT) (Biovision), lactate dehydrogenase (LDH) (Cusabio), total-antioxidant-status (TAS) (Rel assay diagnostics), and total -oxidant-status (TOS) (Rel assay diagnostics) were measured using commercial kits. Triglycerides were measured using commercial kits (Cayman). Serum total cholesterol, high-density lipoprotein (HDL)-cholesterol, and low-density lipoprotein (LDL)-cholesterol levels were analyzed with a Cobas C 6000 autoanalyzer. Superoxide-dismutase (SOD) was estimated by the enzymatic methods. ${ }^{[19]}$ Briefly, the principle of SOD activity determination method was based on the inhibition of nitroblue tetrazolium reduction by the xanthine-xanthine oxidase system as a superoxide radical generator. One unit of SOD was defined as the enzyme activity causing 50\% inhibition in the nitroblue tetrazolium reduction rate. Glutathione-peroxidase (GSH-Px) was estimated by the enzymatic methods. ${ }^{[20]}$ Briefly, GSH-Px as measured by the enzymatic reaction, which was initiated by addition of $\mathrm{H}_{2} \mathrm{O}_{2}$ (Sigma-Aldrich) to the reaction mixture containing reduced glutathione, nicotinamide adenine dinucleotide phosphate (NADPH, Sigma-Aldrich), and glutathione reductase (SigmaAldrich). The change in the absorbance at $340 \mathrm{~nm}$ was monitored using a spectrophotometer (Amersham Biosciences and Cayman Chemical, Ann Arbor, Mich., USA). 
Table 1. Characteristics of experimental animals

\begin{tabular}{lccc} 
& Con $(\mathbf{n}=\mathbf{8})$ & MS $(\mathbf{n}=\mathbf{8})$ & MS-Q $(\mathbf{n}=\mathbf{8})$ \\
\hline Body weight $(\mathrm{g})$ & $353.4 \pm 15.2$ & $455.4 \pm 7.3^{\mathrm{a}}$ & $420.5 \pm 13.4^{\mathrm{a}}$ \\
Blood glucose $(\mathrm{mg} / \mathrm{dL})$ & $139.3 \pm 12.1$ & $365.3 \pm 35.4^{\mathrm{a}}$ & $280.4 \pm 33.2^{\mathrm{a}}$ \\
Insulin $(\mathrm{ng} / \mathrm{ml})$ & $1.49 \pm 0.3$ & $3.41 \pm 0.1^{\mathrm{a}}$ & $2.25 \pm 0.2^{\mathrm{a}}$ \\
HOMA-IR & $9.43 \pm 1.2$ & $26.4 \pm 2.3^{\mathrm{a}}$ & $17.4 \pm 1.3^{\mathrm{a}}$ \\
HOMA- $\beta$ & $0.54 \pm 0.07$ & $0.44 \pm 0.04$ & $0.47 \pm 0.06$ \\
\hline
\end{tabular}

All parameters were expressed as mean \pm standard error (S.E.M.). Con: Control; MS: Metabolic syndrome; MS-Q: Quercetin treated metabolic syndrome group; $n$ : Number of rat for each group; HOMA: Homeostatic model assessment; IR: Insulin resistance; $\mathrm{a}<0.05$ vs. Con.

\section{Thioredoxin-1 (TRX-1) protein level and activity}

Protein level of thioredoxin-1 (TRX-1) was determined by Western blot. Shortly, equal amount of proteins $(20 \mu \mathrm{g})$ from samples were loaded and separated on $10 \%$ sodium dodecyl sulfate-polyacrylamide gel electrophoresis under reducing conditions. After electrophoresis ( $150 \mathrm{~V}, 1.5 \mathrm{~h})$, the samples were electro blotted onto a PVDF membrane (20 V, 2 h). TRX-1 contents in the samples were identified using anti-TRX-1 (12 kD, 1/1000, rabbit, Abcam) antibody. Immunoreactive protein bands were visualized using the $\mathrm{ECL}$ plus detection system. TRX-1 protein levels in liver tissues normalized according to the $\beta$-actin levels in liver tissues from experimental group. TRX-1 activity was measured using commercial kit (Elabscience).

\section{Chemicals}

Unless specified, the reagents used were obtained from Sigma-Aldrich Chemie (Steinheim, Germany). Molecular weight markers and PVDF membranes were purchased from Bio-Rad. To detect proteins with Western blotting, we used ECL Plus reagants, purchased from GE Healthcare.

\section{Statistical analysis}

All parameters were expressed as mean \pm standard error of mean (S.E.M.). Statistical analyses were performed using oneway analysis of variance followed by Bonferroni post-hoc anal$y s i s$. The $p$ values less than 0.05 were considered to be statistically significant.

\section{Results}

At the end of the $20^{\text {th }}$ weeks of experimental period, compared with control rats, the sucrose-fed rats exhibited several characteristics of MS, including central obesity, adiposity, insulin resistance, hyperinsulinemia, and hypertriglyceridemia. MS group blood glucose level was increased significantly approximately 2.5 fold compared with Con group (Table 1 ). Furthermore, these group rats gain weight, increase food and water intake, also increase adiposity during experimental period. Quercetin didn't affect the food intake of treated rats but the steatosis of liver was observed lower in MS-Q group. Serum insulin level of MS group increased significantly approximately
Table 2. Effect of quercetin on AST, ALT, LDH levels in liver tissues of male rats

\begin{tabular}{lccc} 
& Con $(\mathbf{n}=\mathbf{8})$ & MS $(\mathbf{n}=\mathbf{8})$ & MS-Q $(\mathbf{n}=\mathbf{8})$ \\
\hline AST (U/L) & $56.3 \pm 9.3$ & $197.3 \pm 15.4^{\mathrm{a}}$ & $147.4 \pm 12.5^{\mathrm{a}}$ \\
ALT (U/L) & $27.3 \pm 6.5$ & $113.4 \pm 9.5^{\mathrm{a}}$ & $86.2 \pm 7.4^{\mathrm{a}}$ \\
LDH (U/L) & $420.5 \pm 36.4$ & $793.5 \pm 58.1^{\mathrm{a}}$ & $635.4 \pm 35.2^{\mathrm{a}}$ \\
\hline
\end{tabular}

All parameters were expressed as mean \pm standard error (S.E.M.). Con: Control; MS: Metabolic syndrome; MS-Q: Quercetin treated metabolic syndrome group; $\mathrm{n}$ : number of rat for each group; AST: Aspartate transaminase; ALT: Alanine transaminase; LDH: Lactate dehydrogenase; ${ }^{a} \mathrm{p}<0.05$ vs. Con.

2.0 fold compared with Con group. The other marker of MS, HOMA (homeostasis model of assessment) index, for measuring insulin resistance increased compared with the Con group. The serum insulin level of MS-Q group significantly increased compared with Con group (Table 1).

Table 2 showed that AST level significantly increased approximately 3.5 fold in MS as compared to the Con group. MS-Q group showed increases in AST level approximately 4.0 fold as compared with the Con group. The level of ALT increased in MS as compared to the Con group. The level of ALT decreased (not significantly) in quercetin treatment from MS group as compared to the MS group. In MS group, the LDH level significantly increased as compared to the Con group. Quercetin treatment reduced (not significantly) the LDH level in MS group as compared with the MS group.

Figure $1 \mathrm{~A}$ represents SOD as a graph in tissues of liver. SOD in MS group decreased (approximately 1.5 fold) as compared to the Con group. Quercetin treatment significantly increased the level of SOD in liver as compared to the MS group. GSHPx level was shown as a graph in Figure 1B. GSH-Px level significantly decreased (approximately 1.8 fold) in MS group as compared to the Con group. Treatment of quercetin significantly decreased GSH-Px level in MS group. The activities of TAS in MS and MS-Q group in liver tissues showed in Figure 1C. TAS level was significantly decreased (approximately 2.0 fold) in MS as compared to the Con group. Quercetin treatment significantly increased the activities of TAS in liver as compared to the MS rat. The activities of TOS were shown as a graph in Figure 1D in liver tissues. MS group showed significantly increased levels of TOS (approximately 1.5 fold) as compared to the Con group. Quercetin treatment restored these elevated TOS levels in liver tissues of MS but it wasn't significantly.

The effects of quercetin treatment on triglycerides, total cholesterol, HDL-cholesterol, and LDL-cholesterol in the serum of control and MS groups were listed in Table 3. MS group showed significantly an increase in triglycerides (approximately 1.5 fold), total cholesterol (approximately 1.2 fold) and LDL-cholesterol (approximately 3.4 fold) as compared to the Con group. There was a significant decrease in the HDLcholesterol level (approximately 1.8 fold) in the MS group as compared to the Con group. MS-Q group did not show any 


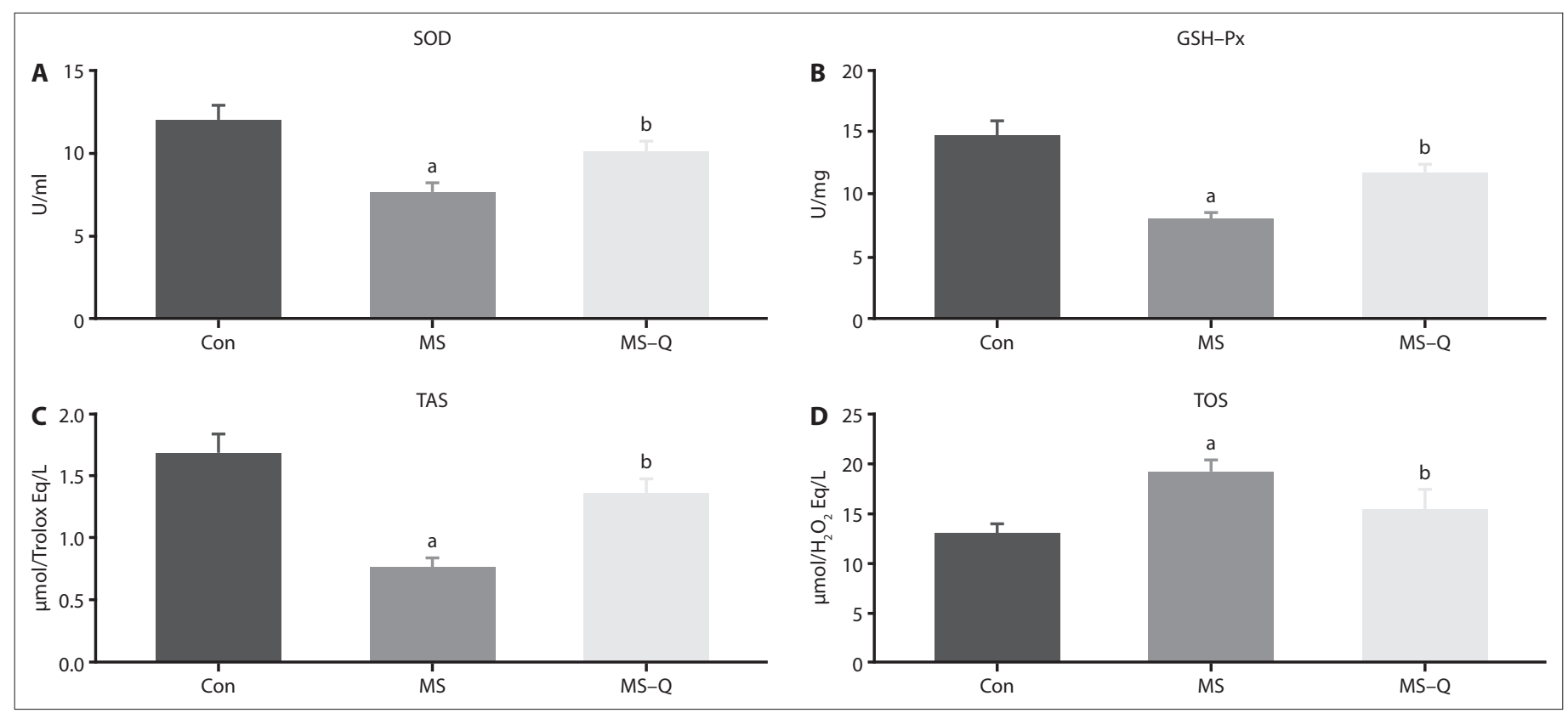

Figure 1. Bar graphs represent the oxidative stress parameters in liver tissues from each experimental group: changes of superoxide dismutase (SOD) (A) and changes of glutathione peroxidase (GSH-Px) (B) total antioxidant status (TAS) (C) and total oxidant status (TOS) (D) in liver of experimental groups. Bar graph was expressed as mean \pm standard error of mean (S.E.M.) from control group (Con, $\mathrm{n}=8$ ), metabolic syndrome group (MS, $n=8$ ), quercetin treated metabolic syndrome group (MS-Q, $n=8$ ). ap $<0.05$ versus Con, bp $<0.05$ versus MS.

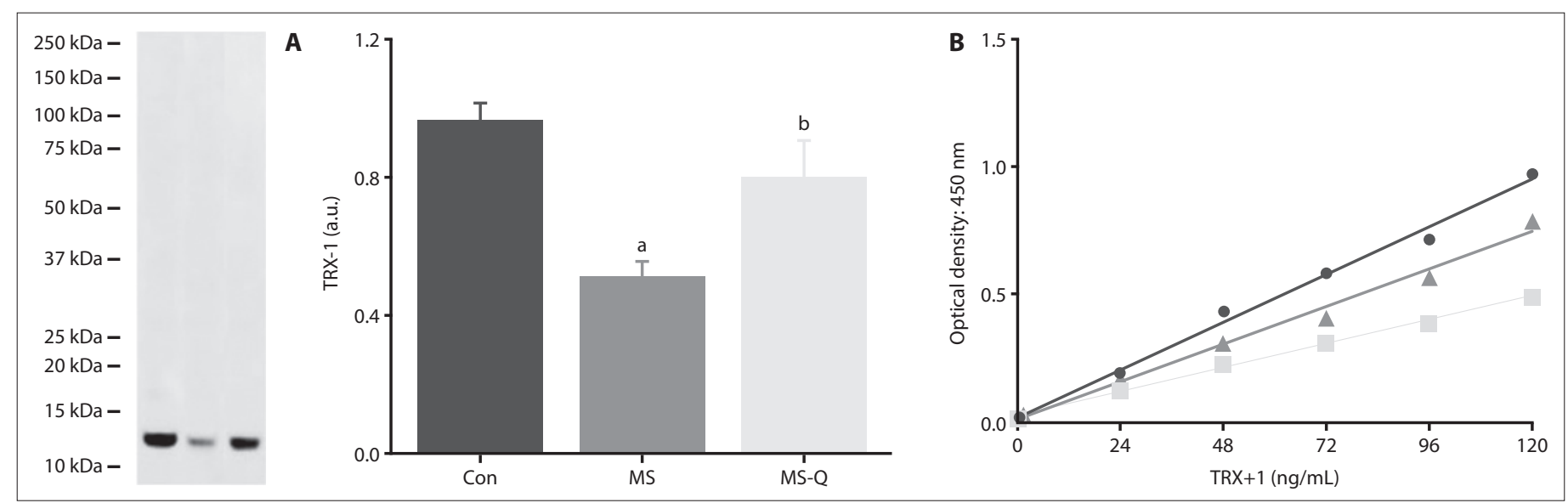

Figure 2. Thioredoxin-1 (TRX-1) protein level and activity. Representative western blot of TRX-1 level (A) for liver in experimental groups is given at the top of the bar graphs. TRX-1 activity is represented in B. Bar graphs were expressed as mean \pm standard error of mean (S.E.M.) from control group (Con, $n=8$ ), metabolic syndrome group (MS, $n=8$ ), quercetin treated metabolic syndrome group (MS-Q, $n=8)$. TRX-1 protein level normalized according to the $\beta$-actin level (not showed). ap $<0.05$ versus Con, $b p<0.05$ versus MS.

significant changes in lipid profile except LDL-cholesterol as compared with the Con group, but there were some decreases in the levels of triglycerides, and LDL-cholesterol of MS-Q group when compared with MS group.

Figure $2 \mathrm{~A}$ and $2 \mathrm{~B}$ showed TRX-1 protein level and activity in experimental groups, respectively. TRX-1 protein level in MS group significantly decreased as compared to the Con group. Quercetin treatment significantly increased TRX-1 protein level in MS group. TRX-1 activity was lower in MS group than control group, but the treatment of quercetin enhanced the activity of TRX-1.

\section{Discussion}

Quercetin's protective role has been reported in animal models of type 1 and type 2 diabetes. In the present study, quercetin shows as an antidiabetic effect via targeting both hyperglycemia and oxidative stress. This was shown by the reduction in blood glucose levels in the quercetin supplemented group.

One of the traits of MS is high insulin resistance. ${ }^{[21]}$ Homeostatic model assessment (HOMA) gives information about the $\beta$-cell function and insulin resistance. In the present study, this HOMA level increased in MS group. Moreover, blood glucose 
Table 3. Effect of quercetin on lipid profile in liver tissues of male rats

\begin{tabular}{lccc} 
& Con $(\mathbf{n}=\mathbf{8})$ & MS $(\mathbf{n}=\mathbf{8})$ & MS-Q $(\mathbf{n = 8})$ \\
\hline Triglycerides $(\mathrm{mg} / \mathrm{dL})$ & $37.5 \pm 3.2$ & $66.2 \pm 4.5^{\mathrm{a}}$ & $47.5 \pm 5.3^{\mathrm{b}}$ \\
Total cholesterol $(\mathrm{mg} / \mathrm{dL})$ & $127.2 \pm 5.3$ & $153.1 \pm 6.3^{\mathrm{a}}$ & $138.2 \pm 4.5$ \\
HDL cholesterol $(\mathrm{mg} / \mathrm{dL})$ & $57.0 \pm 6.1$ & $31.5 \pm 4.5^{\mathrm{a}}$ & $44.3 \pm 3.2$ \\
LDL cholesterol $(\mathrm{mg} / \mathrm{dL})$ & $8.5 \pm 0.5$ & $29.3 \pm 3.2^{\mathrm{a}}$ & $17.2 \pm 2.2^{\mathrm{a}, \mathrm{b}}$ \\
\hline
\end{tabular}

At the end of the experimental period, animals were anesthetized after being deprived of food for $12 \mathrm{~h}$. All parameters were expressed as mean \pm standard error (S.E.M.). Con: Control; MS: Metabolic syndrome; MS-Q: Quercetin treated metabolic syndrome group; $n$ : Number of rat for each group; HDL: High-density lipoprotein; LDL: Low-density lipoprotein; ${ }^{a} p<0.05$ vs. Con; ${ }^{\mathrm{bp}}<0.05$ vs. MS

and insulin levels increased in MS group. These results showed that the animal model of MS truly occurred.

In MS, oxidative stress develops and alters both non-enzymatic and enzymatic antioxidant defenses. ${ }^{[22]}$ Intracellular redox balance is maintained by GSH. GSH detoxifies various xenobiotics as well as scavenging free radicals. ${ }^{[23]}$ Enzymes of glutathione cycle namely GST and GPx utilize GSH during their reactions.

In a previous study about the model of sodium azide induced hepatic toxicity from sera showed that ALT, AST levels increased and treatment of quercetin decreased to these values to that of control animals. ${ }^{[24]}$ Sonmez et al. ${ }^{[25]}$ studied the toxicity of hydroxyapatite nanoparticles in rat liver cell model. They observed that LDH level increased in this group. Similarly, in the present study, AST, ALT and LDH level in liver tissues increased in MS group. Treatment of quercetin had drawn closer to the values of the control group (not significantly).

SOD catalyzes the dismutation of the superoxide $\left(\mathrm{O}_{2}^{-}\right)$radicals. Also, it is an important antioxidant defense in all living cells when exposed to oxygen. In a previous study, SOD activity decreased in liver tissues from animal model of type 2 diabetes. [26] Supplementation of quercetin increased significantly this level to that of control. In the present study, SOD and GSH-Px levels in liver tissues of MS group decreased significantly compared with the Con group. Treatment of quercetin increased these levels significantly when compared to Con group. These decrements occur may be due to lipid peroxyl radicals and from inactivation of their destruction products.

TAS is an agent for investigating the association between diet and oxidative stress. ${ }^{[27]}$ In the present study, TAS level in MS group decreased significantly compared with the Con group. Oral application of quercetin in MS group increased significantly to that of Con group. Furthermore, TOS level increased significantly in MS group compared with the Con group and quercetin treatment decreased significantly compared with the MS group.

The daily supplementation of $250 \mathrm{mg}$ quercetin in patients with type 2 diabetes in our study exerted no beneficial effect on triacylglycerol, total, LDL and HDL cholesterol. ${ }^{[28]}$ Sahebkar et al. ${ }^{[29]}$ showed that quercetin is a possible new agent to improve metabolic health, since it lowers plasma triglycerides levels. Also, another previous study showed that triglycerideslowering effect of quercetin may, at least in part, be due to increased triglycerides-derived fatty acid uptake by subcutaneous white adipose tissue as a consequence of browning. However, the results of our present study showed elevated triglycerides, total cholesterol and LDL cholesterol level while decreased HDL cholesterol level. Quercetin supplementation resulted in significant alterations in lipid profile compared with Con group.

In this study, MS induced significant decrease in TRX-1 level. Thioredoxins are redox-active proteins that play a protective role against degenerative diseases associated with oxidative stress, including diabetes. ${ }^{[30]}$ Okuyama et al. ${ }^{[31]}$ showed that TRX inhibits thioacetamide-induced acute hepatitis and ethanolinduced hepatocyte damage via its anti-oxidative action. It has been shown that patients with glucose intolerance have high plasma levels of TRX-1 ${ }^{[30]}$ and serum TRX-1 level of type 2 diabetic patients was elevated. ${ }^{[32]}$ However, in the present study, we found that tissue TRX-1 level is significantly lower than Con group. Quercetin treatment increased significantly this level to that of Con level.

In conclusion, it has been found that administration of quercetin enhances tissue protection in MS rats via the improvement of the compromised antioxidant defense system. Quercetin has a protective effect on upregulation of TRX-1 in MS rats. Our results may provide further research on the role of quercetin supplementations to protect against MS and its complications.

Acknowledgment: I would like to thank Prof. Dr. Belma Turan and Dr. M. Fulya Tutar Selçuk for their departmental encouragement.

Conflict of interest: There are no relevant conflicts of interest to disclose.

Financial Support and Sponsorship: This study was supported by TUBITAK-SBAG-115S827 and Ankara Yıldırım Beyazıt University Projects Office-2864.

\section{References}

1. Ando K, Fujita T. Metabolic syndrome and oxidative stress. Free Radic Biol Med 2009;47:213-18.

2. Vincent HK, Taylor AG. Biomarkers and potential mechanisms of obesity induced oxidant stress in humans. Int J Obes 2006;30:40018.

3. Sies H. Oxidative stress: Oxidants and antioxidants London: San Diego; 1991.

4. Cabre M, Comps J, Paternain JL et al. Time course of changes in hepatic lipid peroxidation and glutathione metabolism in rats with carbon tetrachloride-induced cirrhosis. Clin Exp Pharmacol Physiol 2000;27:694-9.

5. Vincent A.M, Russell JW, Low P et al. Oxidative stress in the pathogenesis of diabetic neuropathy. Endocrine Reviews 2004;25:61228.

6. Altan N, Dinçel AS, Koca C. Diabetes mellitus and oxidative stress. Turkish J Biochem 2006;31:51-6. 
7. Lonardo A, Ballestri S, Marchesinin G et al. Nonalcoholic fatty liver disease: A precursor of the metabolic syndrome. Dig Liver Dis 2015;47:181-90.

8. Lonardo A, Nascimbeni F, Mantovani A et al. Hypertension, diabetes, atherosclerosis and NASH: Cause or consequence? J Hepatol 2018;68:335-52.

9. Aguirre L, Arias N, Macarulla MT et al. Beneficial effects of quercetin on obesity and diabetes. The Open Nutraceuticals $\mathrm{J}$ 2011;4:189-98.

10. Saija A, Scalese M, Lanza M et al. Flavonoids as antioxidant agents: importance of their interaction with biomembranes. Free Radic Biol Med 1995;19:481-6.

11. Kim HP, Mani I, Ziboh VA. Effects of naturally-occurring flavonoids and bio-flavonoids on epidermal cyclooxygenase from guineapigs. Prostaglandins Leukot Essent Fatty Acids 1998;58:17-24.

12. Arne'r ES, Holmgren A. The thioredoxin system in cancer. Semin Cancer Biol 2006;16:420-6.

13. Collet JF, Messens J. Structure, function, and mechanism of thioredoxin proteins. Antioxid Redox Signal. 2010;13:1205-16.

14. Yamawaki $\mathrm{H}$, Berk BC. Thioredoxin: a multifunctional antioxidant enzyme in kidney, heart and vessels. Curr Opin Nephrol Hypertens 2005;14:149-53.

15. Ballestri S, Nascimbeni F, Baldelli E et al. NAFLD as a Sexual Dimorphic Disease: Role of Gender and Reproductive Status in the Development and Progression of Nonalcoholic Fatty Liver Disease and Inherent Cardiovascular Risk. Adv Ther 2017;34:1291-326.

16. Ruiz-Ramirez A, Chavez-Salgado M, Peneda-Flores JA et al. Highsucrose diet increases ROS generation, FFA accumulation, UCP2 level, and proton leak in liver mitochondria. Am J Physiol Endocrinol Metab 2011;301:E1198-207.

17. Matthews DR, Hosker JP, Rudenski AS et al. Homeostasis model assessment: insulin resistance and beta-cell function from fasting plasma glucose and insulin concentrations in man. Diabetologia 1985;28:412-9.

18. Vasques AC, Rosado LE, Cassia GR et al. Critical analysis on the use of the homeostasis model assessment (HOMA) indexes in the evaluation of the insulin resistance and the pancreatic beta cells functional capacity. Arq Bras Endocrinol Metabol 2008;52:32-9.

19. Sun Y, Oberley LW, Li Y. A simple method for clinical assay of superoxide dismutase. Clin Chem 1988;34:497-500.

20. Paglia DE, Valentine WN. Studies on the quantitative and qualita- tive characterization of erythrocyte glutathione peroxidase. J Lab Clin Med 1967;70:158-69.

21. Kim SH, Sung KC, Reaven GM. Utility of Homeostasis Model Assessment of $\beta$-Cell Function in Predicting Diabetes in 12,924 Healthy Koreans. Diabetes Care 2010;33: e72.

22. Delbosc S, Paizanis E, Magous R et al. Involvement of oxidative stress and NADPH oxidase activation in the development of cardiovascular complications in a model of insulin resistance, the fructose-fed rat. Atherosclerosis 2005;179:43-9.

23. Pompella A, Visvikis A, Paolicchi $A$ et al. The changing faces of glutathione, a cellular protagonist. Biochem Pharmacol 2003; 66:1499-503.

24. Somade OT, Akinloye OA, Adeyeye MO et al. Quercetin, a natural phytochemical and antioxidant protects against sodium azideinduced hepatic and splenic oxidative stress in rats. A J Physiol Biochem Pharmacol 2015;4: 69-74.

25. Sonmez E, Cacciatore I, Bakan F et al. Toxicity assessment of hydroxyapatite nanoparticles in rat liver cell model in vitro Human and Experimental Toxicology 2016;35:1-11.

26. Alam M, Meerza $D$, Naseem I. Protective effect of quercetin on hyperglycemia, oxidative stress and DNA damage in alloxan induced type 2 diabetic mice. Life Sciences 2014;109:8-14.

27. Serafini M, DelRio D. Understanding the association between dietary antioxidants, redox status and disease: is the Total Antioxidant Capacity the right tool? Redox Rep 2004;9:145-52.

28. Mazloom Z, Abdollahzadeh SM, Dabbaghmanesh MH et al. The Effect of Quercetin Supplementation on Oxidative Stress, Glycemic Control, Lipid Profile and Insulin Resistance in Type 2 Diabetes: A Randomized Clinical Trial. J Health Sci Surveillance Sys January 2014; Vol 2; No 1.

29. Sahebkar, A. Effects of quercetin supplementation on lipid profile: A systematic review and meta-analysis of randomized controlled trials. Crit Rev Food Sci Nutr 2017;57:666-76.

30. Miyamoto S, Kawano H, Hokamaki J et al. Increased plasma levels of thioredoxin in patients with glucose intolerance. Intern Med 2005;44:1127-32.

31. Okuyama $H$, Nakamura $H$, Shimahara $Y$ et al. Overexpression of thioredoxin prevents acute hepatitis caused by thioacetamide or lipopolysaccharide in mice. Hepatology 2003;37:1015-25.

32. Kakisaka Y, Nakashima T, Sumida $Y$ et al. Elevation of serum thioredoxin levels in patients with type 2 diabetes. Hom Metab Res 2002;34:160-4. 